\title{
Acute kidney injury due to rhabdomyolysis after status epilepticus: Two pediatric case reports
}

\author{
Status Epileptikusa bağlı rabdomiyoliz ve akut böbrek hasarı: Iki pediatrik olgu sunumu
}

A. Midhat Elmacı ${ }^{1}$, Fatih Akın², Erhan Aksoy ${ }^{3}$

\begin{abstract}
Rhabdomyolysis is defined as degeneration of skeletal muscle due to traumatic or non-traumatic causes. With the injury of sarcolemma, myocyte contents (myoglobin, enzymes and electrolytes) leakage into the plasma and urine occurs. If rhabdomyolysis is not recognized and untreated, severe even fatal complications such as acute kidney injury (AKI), hypocalcemia, hyperkalemia, hypovolemia, muscle necrosis, cardiac arrythmias and compartment syndrome may occur. Status epilepticus is an uncommon cause of rhabdomyolysis and myoglobinuria. We report here two pediatric patients, who developed myoglobinuria and AKI due to status epilepticus. J Clin Exp Invest 2013; 4 (4): 443-446
\end{abstract}

Key words: Epilepsy, child, rhabdomyolysis, kidney injury

\section{INTRODUCTION}

Rhabdomyolysis is a potentially life-threatening syndrome that can develop from a variety of causes. The most common causes of rhabdomyolysis in adults are illicit drugs, alcohol abuse, medical drugs, muscle diseases, trauma, neuroleptic malignant syndrome, seizures and immobility. Whereas in pediatric patients, the most common causes are viral myositis, trauma, connective tissue disorders, exercise, and drug overdose. With the injury of sarcolemma, myocyte contents (myoglobin, enzymes and electrolytes) leakage into the plasma and urine occurs [1]. The diagnosis is based on clinical symptoms and signs, and laboratory tests. Initial signs are non-specific and are related to the primary disorder. It can be presented with general and muscle weakness, increased body temperature and gener-

\section{ÖZET}

Rabdomiyoliz, travmatik veya non-travmatik sebeplerle çizgili kas hücrelerinin hasara uğramasıdır. Hasar sonrası kas hücre içeriği (miyoglobin, enzim ve elektrolitler) dolaşıma katılır. Rabdomiyoliz teşhis ve tedavi edilmezse akut böbrek hasarı (ABH), hipokalsemi, hiperkalemi, hipovolemi, kas nekrozu, kardiyak aritmi ve kompartman sendromu gibi ciddi komplikasyonlara neden olabilir. Status epileptikus, rabdomiyoliz ve miyoglobinürinin nadir sebeplerindendir. Bu yazıda status epileptikus sonrası miyoglobinüri ve $\mathrm{ABH}$ gelişen iki pediatrik olgu sunulmuştur.

Anahtar kelimeler: Epilepsi, çocuk, rabdomiyoliz, böbrek hasarı

alized or local muscle pains. Laboratory tests made to confirm the diagnosis reveal high serum levels of creatine phosphokinase (CK) and myoglobin, and myoglobinuria demonstrated by a blood-positive dipstick in the absence of red blood cells in the urinary sediment. If rhabdomyolysis is not recognized and untreated, severe even fatal complications such as acute kidney injury (AKI), hypocalcemia, hyperkalemia, hypovolemia, muscle necrosis, cardiac arrythmias, compartment syndrome and disseminated intravascular coagulation may ensue. The incidence of $\mathrm{AKI}$ in rhabdomyolysis ranges from $10 \%$ to $40 \%[2,3]$.

Data on seizure-associated rhabdomyolysis in children are limited. These two cases emphasize the importance of this rare occurrence of myoglobinuria and $\mathrm{AKI}$ in patients with status epilepticus.

\footnotetext{
${ }^{1}$ Dr. Faruk Sukan Obstetric and Children's Hospital, Department of Pediatric Nephrology, Konya, Turkey

${ }^{2}$ Konya Education and Research Hospital, Department of Pediatrics, Konya, Turkey

${ }^{3}$ Dr. Faruk Sukan Obstetric and Children's Hospital, Department of Pediatric Neurology, Konya, Turkey
}

Correspondence: Ahmet Midhat Elmacl,

Dr. Faruk Sukan Obstetric and Children's Hospital, Dept. Pediatric Nephrology, Konya, Turkey Email: drmidhat@hotmail.com

Received: 06.09.2013, Accepted: 24.09.2013

Copyright (C JCEI / Journal of Clinical and Experimental Investigations 2013, All rights reserved 


\section{CASE 1}

A 30 months-old boy was admitted to the emergency department of our hospital due to status epilepticus and cardiopulmonary arrest. After a nearly 2-minutes long cardiopulmonary resuscitation (CPR) a normal sinus rhythm was obtained. He was treated with intravenous anti-epileptics and mechanical ventilation was performed after intubation. There was no history of fever, trauma, and use of drug or toxic substances. His motor and mental development was normal and he had no family history for seizures or kidney disease. On the physical examination the systolic blood pressure was 60/34 $\mathrm{mmHg}$, temperature was $36.4^{\circ} \mathrm{C}$. He had a Glasgow coma score of 3 .

Laboratory studies on admission showed the following data; hemoglobin $12.8 \mathrm{~g} / \mathrm{dL}$, white blood cells $15400 / \mathrm{mm}^{3}$, platelets $293000 / \mathrm{uL}$, serum creatinine $1 \mathrm{mg} / \mathrm{dL}$, BUN $39 \mathrm{mg} / \mathrm{dL}$, uric acide $12.9 \mathrm{mg} /$ dL, LDH 1366 u/L, CK 18879 u/L (N=0-145 u/L), sodium $137 \mathrm{mEq} / \mathrm{L}$, potassium $5.8 \mathrm{mEq} / \mathrm{L}$, myoglobin $15375 \mu \mathrm{g} / \mathrm{L}(\mathrm{N}=0-76 \mu \mathrm{g} / \mathrm{L})$. Arterial blood gas analysis revealed $\mathrm{pH} 7.31, \mathrm{HCO}_{3} 18.6, \mathrm{pCO}_{2} 41 \mathrm{~mm} \mathrm{Hg}$. The urine was dark brown in colour, and urine dipstick was positive for blood in the absence of urinary erythrocytes in the sediment. Urine myoglobin was $287.9 \mu \mathrm{g} / \mathrm{L}(\mathrm{N}=<30 \mu \mathrm{g} / \mathrm{L})$. Biochemical investigation to exclude metabolic disorders, (lactate, pyruvate, aminoacids in plasma, and organic acids in urine) revealed normal levels. Computerize tomography of the brain showed cerebral eudema. Ultrasonography revealed normal kidneys and bladder. With these findings rhabdomyolysis and cerebral eudema diagnosis were obtained. Mannitol, and urine alkalinization was started. Less than 48 hours later, the patient suddenly developed an acute rise in creatinine and urea levels and became anuric. Peritoneal dialysis was performed because of AKI. Multiorgan failure developed during the follow-up and he died 5 days after admission.

\section{CASE 2}

A 15 year-old girl was admitted to the emergency department in our hospital due to status epilepticus. She continued to experience generalized tonicclonic seizures. She was treated with intravenous anti-epileptics. Following treatment with sodium valproate, no more seizure was seen. There was no history of fever, trauma, and use of drug or toxic substances. She had a brother 18 years-old with epilepsy, a 17 year-old healthy brother, and two brothers who were dead 1 week and 1 day after birth. Systolic blood pressure was $120 / 70 \mathrm{mmHg}$, temperature was $37.1^{\circ} \mathrm{C}$. Physical examination was normal except muscle weakness.

Laboratory studies on admission showed the following data; hemoglobin $11.9 \mathrm{~g} / \mathrm{dL}$, white blood cells $10800 / \mathrm{mm} 3$, platelets $185000 / \mathrm{uL}$, serum creatinine $1.22 \mathrm{mg} / \mathrm{dL}$, BUN $37 \mathrm{mg} / \mathrm{dL}$, uric acide $9.7 \mathrm{mg} /$ $\mathrm{dL}$, sodium $141 \mathrm{mEq} / \mathrm{L}$, potassium $5.2 \mathrm{mEq} / \mathrm{L}$. The urine was dark brown in colour, and urine dipstick positive for blood in the absence of urinary erythrocytes in the sediment. Serum myoglobin $1217 \mu \mathrm{g} / \mathrm{L}$, LDH 755 u/L, CK 4185u/L, and urine myoglobin level was $608 \mu \mathrm{g} / \mathrm{L}$. Ultrasound and radionuclide scanning of kidneys were normal. Magnetic resonance imaging of the brain showed no abnormalities. Electroencephalography revealed cerebral dysfunction and considered to be the finding of postictal period. Thyroid disease was ruled out and autoimmune serology (antinuclear antibodies, antidouble-stranded DNA, antithyroid peroxidase, lupus anticoagulant, and anticardiolipins) was negative and complement C3 and C4 levels were in normal range. Antibodies against viral pathogens including Cytomegalovirus, Herpes Simplex virus and Epstein-Barr virus were negative. To exclude metabolic disorders, biochemical investigation (lactate, pyruvate, aminoacids in plasma, and organic acids in urine) was normal.

The patient follow-up developed an acute rise in creatinine and urea levels and became anuric. Serum BUN 83 mg/dL, creatinine $3.7 \mathrm{mg} / \mathrm{dL}$, Haemodialysis was initiated with clinical improvement. After five sessions, blood urea (34 $\mathrm{mg} / \mathrm{dL})$ and serum creatinine $(0.9 \mathrm{mg} / \mathrm{dL})$ levels improved over 12 days. Serum CK and myoglobin levels decreased until normalization.

\section{DISCUSSION}

Rhabdomyolysis is a potentially life-threatening syndrome characterized by muscle necrosis and the release of intracellular muscle contents into the circulation. Excess myoglobin may thus cause renal tubular obstruction, direct nephrotoxicity, and AKI [1]. Rhabdomyolysis may be inherited or acquired. Most common hereditary cause is McArdle disease, which is related to myophosphorilase deficiency. The acquired causes include crush injuries, excessive musculer activity (seizures), burns, viral and bacterial infections, drugs and toxins (alcohol, cocaine overdose), exercise and malignant hyperthermia [4]. Both of our cases did not have a history of fever, trauma, and use of drug or toxic substances. Case 2 had a family history of epilepsy.

Increased levels of CK activity are also observed in patients survived from CPR. Mattana et 
al. reported that $68.3 \%$ of 63 patients survived following CPR developed rhabdomyolysis, but none of them had developed AKI. This rhabdomyolysis showed a direct relationship with the number of chest compressions and electrical injury [5]. CPR may have contributed to rhabdomyolysis in case 1 reported here. He had experienced a short time CPR, which took nearly 2-minutes. This short duration, absence of a defibrillation or cardioversion and the development of AKI suggest that rhabdomyolysis in our patient is mainly due to status epilepticus.

The clinical findings of rhabdomyolysis vary depending on the underlying cause. Fever, loss of a function of a muscle or muscle weakness, a diffuse or local myalgia and edema are common clinical signs. Tea-colored urine is a classical manifestation of rhabdomyolysis. Changes in mental status occur occasionally, either secondary to urea-induced encephalopathy or related to the underlying aetiology $[1,6]$. Case 1 was in a comatose state after the cardiopulmonary arrest. Case 2 had diffuse myalgia. Both of our cases had tea-coloured urine.

The definitive diagnosis of rhabdomyolysis should be made by laboratory tests including serum $\mathrm{CK}$ and urine myoglobin. CK is the marker most commonly used to guide the diagnosis and therapy in daily clinical practice [6]. A five times higher than the normal value of CK confirms the diagnosis [1]. Myoglobin is bound to plasma proteins and serum concentration is very low in the circulation. After rhabdomyolysis its serum level increases. Serum myoglobin is filtered by the glomerulus and excreted by urine, leading to myoglobinuria. Myoglobinuria does not occur without rhabdomyolysis, and elevated serum myoglobin and myoglobinuria are reliable parameters for rhabdomyolysis. Quantitative urine myoglobin measurement by radioimmunassay method is more sensitive and specific method for determining myoglobinuria than a urine dipstick method $[1,7]$. El-Abdellati et al. reported that serum and urine miyoglobin levels showed significant positive correlation for predicting AKI and achieved peak levels earlier than CK [4]. Both of our cases had high levels of serum and urine myoglobin levels on admission and both had developed AKI.

AKI is the most important complication of rhabdomyolysis. Rhabdomyolysis accounts for $7 \%$ of all cases of AKI in the USA. In some limited and inconclusive studies rhabdomyolysis incidence in children is reported to be $0.26 \%$, and $42-50 \%$ of these children developed AKI [8-10]. Nevertheless, Mannix et al. reported that retrospective study including all children with high CK after admission to the emergency department, excluding children with muscular diseases, 5\% developed AKI [9]. Although the exact mechanisms by which rhabdomyolysis impairs glomerular filtration rate are unclear. Some evidence suggests that the mechanisms of renal damage may include; intrarenal vasoconstriction and ischemia, direct and indirect ischemic tubule injury and tubular obstruction $[1,8,10]$. Excessive muscular activity such as status epilepticus, results in a state in which ATP production cannot keep up with the demand, subsequently exhausting cellular energy supplies leading to a disruption of muscle cell membranes [1]. Especially the urine level $>300$ $\mathrm{ng} / \mathrm{ml}$ of myoglobin is associated with more frequent AKI [11]. Both of our cases needed renal replacement therapy for the treatment of $\mathrm{AKI}$, which was developed due to myoglobinuria after status epilepticus.

Fluid therapy and bicarbonate therapy are standard prophylactic treatments for the prevention of AKI secondary to rhabdomyolysis. No specific guidelines exist for children. The main therapeutic approach is fluid therapy and hydration to maintain good urine output (at least $1-2 \mathrm{ml} / \mathrm{kg} / \mathrm{h}$ ), and this treatment usually needs to be aggressive and started early. Alkalinization of urine may decrease cast formation by inhibiting the formation of ferrihemate, myoglobin casts $[8,10]$. A mannitol-induced forced osmotic diuresis has both renal and extrarenal effects that may play a role in preventing rhabdomyolysis-associated AKI. Mannitol therapy may also be associated with complications associated with extracellular fluid shifts in the brain and at large doses may actually worsen AKI. The indications for renal replacement therapy in these patients were severe hyperkalemia, acidosis, and oligo-anuric AKI. Intermittent conventional hemodialysis can be used successfully and will quickly correct electrolyte and fluid disturbances in the patient. Nevertheless, patients with multiple-organ-dysfunction syndrome who are hemodynamically unstable will better tolerate continuous renal replacement therapy [8]. Renal replacement therapy was indicated for case 1 and peritoneal dialysis was performed because the patient was an infant. The patient was dead after multiorgan failure had developed. A continuous renal replacement therapy could have been more beneficial but as this method needed a central vascular access, peritoneal dialysis was preferred. Hemodialysis was successful for the treatment of second case with a complete recovery.

In conclusion, rhabdomyolysis due to status epilepticus is rare in children and it can cause serious morbidity and mortality. Hemodialysis is an effective therapy in children developing AKI after rhabdomy- 
olysis and continuous renal replacement therapy is preferable in patients with multiorgan failure.

\section{REFERENCES}

1. Khan FY. Rhabdomyolysis: a review of the literature. Neth J Med 2009;67:272-283.

2. Hojs R, Ekart R, Sinkovic A, Hojs-Fabjan T. Rhabdomyolysis and acute renal failure in intensive care unit. Ren Fail 1999;21:675-684.

3. Holt S, Moore K. Pathogenesis of renal failure in rhabdomyolysis: the role of myoglobin. Exp Nephrol 2000;8:72-76.

4. El-Abdellati E, Eyselbergs M, Sirimsi H, et al. An observational study on rhabdomyolysis in the intensive care unit. Exploring its risk factors and main complication: acute kidney injury. Ann Intensive Care 2013;3:8 doi: 10.1186/2110-5820-3-8.

5. Mattana J, Singhal PC. Determinants of elevated creatine kinase activity and creatine kinase MB-frac- tion following cardiopulmonary resuscitation. Chest 1992;101:1386-1392.

6. Huerta-Alardín AL, Varon J, Marik PE Bench-to-bedside review: Rhabdomyolysis -- an overview for clinicians. Crit Care 2005;9:158-169.

7. Gabow PA, Kaehny WD, Kelleher SP. The spectrum of rhabdomyolysis. Medicine 1982;61:141-152.

8. Al-Ismaili Z, Piccioni M, Zappitelli M. Rhabdomyolysis: pathogenesis of renal injury and management. Pediatr Nephrol 2011;26:1781-1788.

9. Mannix R, Tan ML, Wright R, Baskin M. Acute pediatric rhabdomyolysis: causes and rates of renal failure. Pediatrics 2006;118:2119-2125.

10. Elsayed EF, Reilly RF. Rhabdomyolysis: a review, with emphasis on the pediatric population. Pediatr Nephrol 2010;2:7-18.

11. Kim KK. Exogenous causes of myoglobinuria- review of 26 cases. J Korean Med Sci 1996;11:342-346. 